\title{
ANALISIS DOSIS RADIASI PADA JARINGAN TUMOR DENGAN SIMULASI PROGRAM MCNP-5
}

\author{
Tumpal Pandiangan ${ }^{1}$, Ika Bali ${ }^{2}$ \\ ${ }^{1}$ Program Studi Fisika, Universitas Matana \\ Email: tumpal@matanauniversity.ac.id \\ ${ }^{2}$ Lembaga Penelitian, Universitas Matana \\ Email: ika.bali@matanauniversity.ac.id
}

Masuk: 28-09-2020, revisi: 23-10-2021, diterima untuk diterbitkan: 25-10-2021

\begin{abstract}
ABSTRAK
Pengukuran setiap dosis radiasi pada organ pasien tidak dimungkinkan secara langsung. Pada umumnya untuk memperkirakan dosis yang diserap oleh organ tubuh manusia didekati dengan pengukuran pada phantom manusia, namun pendekatan ini juga masih terlalu kasar karena komposisi phantom tidak mudah dibuat sama dengan komposisi organ yang sebenarnya. Sehingga saat ini, untuk hal-hal yang penting seperti ketepatan penentuan dosis serap oleh organ tubuh manusia, digunakan metode simulasi Monte Carlo (MCNP) dengan perangkat lunak khusus. Hal ini mendorong meningkatnya keinginan para ilmuwan melakukan transisi dari penggunaan phantom ke penggunaan komputasi perangkat lunak untuk aplikasi fisika medis. Namun sampai saat ini belum tersedia dokumen komprehensif yang ditulis untuk memperkenalkan penggunaan program MCNP guna mensimulasikan aplikasinya dalam fisika medis. Tujuan penelitian ini adalah menganalisis dosis serap radiasi gamma pada jaringan tumor di payudara melalui simulasi perubahan jarak dan besar tumor menggunakan program MCNP-5. Hal ini dapat berguna dalam memastikan penerapan proteksi radiasi pada pasien dan lingkungan tempat pasien. Hasil penelitian menunjukkan dosis radiasi pada sel 1 (jaringan tumor) dengan perubahan jarak antara sumber radiasi dengan sel 1 semakin besar, mengakibatkan besar dosis di sel 1 semakin menurun, sedangkan pengaruh volume sel 1 yang semakin besar maka dosis yang diterima sel 1 semakin besar juga. Selain itu, melalui simulasi ini dapat diketahui untuk setiap penambahan $1 \mathrm{~cm}^{3}$ volume sel 1 jaringan tumor dapat meningkatkan energi serap sebesar 3,5x10e-12 Gray.
\end{abstract}

Kata Kunci: MCNP-5; simulasi; dosis radiasi; jaringan tumor

\begin{abstract}
Direct measurement of each radiation dose to the patient's organs is not possible. In general, to estimate the dose absorbed by human organs is approached by measurements in human phantoms, but this approach is still too rough because the composition of phantoms is not easily made the same as the actual organ composition. Currently, for important matters such as the accuracy of determining the absorption dose by human organs, the Monte Carlo simulation method (MCNP) with special software is used. This has led to a growing desire for scientists to make the transition from using phantoms to computing software for medical physics applications. However, until now no comprehensive document has been written to introduce the use of the MCNP program to simulate its application in medical physics. The purpose of this study was to analyze the absorbed dose of gamma radiation in tumor tissue in the breast by simulating changes in distance and tumor size using the MCNP-5 program. This can be useful in ensuring the application of radiation protection to the patient and the environment in which the patient is located. The results showed that the radiation dose in cell 1 (tumor tissue) with a change in the distance between the radiation source and cell 1 was getting bigger, resulting in a decrease in the dose in cell 1, while the effect of cell volume 1 was greater, the greater the dose received by cell 1. In addition, through this simulation it can be seen that for each addition of $1 \mathrm{~cm}^{3}$ the volume of cell 1 for tumor tissue can increase the absorption energy by $3.5 \times 10$ - 12 Gray.
\end{abstract}

Keywords: MCNP-5; simulation; radiation dose; tumor tissue 


\section{PENDAHULUAN}

Pemantauan dosis radiasi yang diterima oleh organ tubuh manusia selama pemeriksaan dengan alat medis radiasi seperti metode bracytherapy payudara (Skowronek, 2017) tidak dapat diabaikan, bahkan merupakan suatu keharusan agar dapat memastikan dampak radiasi terhadap keselamatan pasien dan pekerja radiasi. Setiap perlakuan paparan radiasi pada pasien harus menerapkan prinsip proteksi radiasi, yaitu menerapkan radiasi serendah mungkin dengan kualitas diagnostik sebaik mungkin bagi pasien (Pandiangan et al, 2019). Beberapa perangkat lunak pemantauan dosis telah dikembangkan guna memantau dan mengontrol distribusi dosis sebelum (Pandiangan et al, 2020) dan selama pemeriksaan pasien menggunakan alat medis radiasi pengion.

Penggunaan sinar-X/y dalam aplikasi medis adalah berasal dari sumber paparan radiasi pengion. Sejak ditemukannya, sinar-X/Y telah banyak digunakan di berbagai aplikasi medis yang berfungsi sebagai alat untuk diagnostik dan terapi bagi pasien. Dosimetri organ tubuh sangat berguna untuk keselamatan pasien dari paparan radiasi dan penilaian potensi risiko dari radiasi. Penyelidikan dosimetri organ tubuh dan risiko dari radiasi telah banyak dilakukan para ilmuan fisikawan medis (Sechopoulos et al, 2017 dan 2018, Bor et al, 2008, Olgar et al, 2012, Dance, 1990).

Dalam penyelidikan risiko kanker pada organ tubuh pasien, penting mengetahui besarnya ratarata dosis pada kelenjar tubuh pasien. Dosis kelenjar rata-rata yang diterima oleh pasien dapat digambarkan sebagai energi yang disimpan persatuan massa jaringan kelenjar rata-rata. Diyakini bahwa kelenjar jaringan di dalam payudara paling sensitif terhadap karsinogenesis yang diinduksi oleh paparan radiasi (Diffey et al, 2014). Besarnya nilai tebal paruh (HVL) dari sinar$\mathrm{X}$, dapat dihitung dari pengukuran kerma udara dengan dan tanpa filter aluminium, atau juga dapat diukur secara langsung menggunakan dosimetri sistem keadaan padat (Ramos et al, 2005). Dalam perhitungan seperti itu, metode Monte Carlo telah menunjukkan kemampuan yang signifikan untuk studi optimasi dalam radiologi diagnostik, fisika radiasi dan dosimetri.

Perhitungan Monte Carlo (MCNP) menggunakan transportasi elektron langsung dan atau foton yang dihasilkan di target. Selain itu, simulasi Monte Carlo terbukti paling cocok sebagai alat teoritis yang kuat untuk perhitungan spektra x-ray dalam geometri kompleks. Banyak studi mamografi telah menggunakan metode Monte Carlo untuk perhitungan dosis kelenjar payudara dan realisasinya untuk mengamati indeks kualitasnya (Aznar et al, 2005, Koutalonis et al, 2007, Douglas \& Kuruvilla, 2000).

Tujuan penelitian ini adalah untuk menganalisis dosis serap radiasi gamma pada jaringan tumor di payudara dengan menggunakan program simulasi perubahan jarak dan volume tumor menggunakan MCNP-5. Hasil analisis dosis serap ini dapat berguna dalam memastikan penerapan proteksi radiasi pada pasien dan lingkungan tempat pasien. Selain itu juga dapat berguna sebagai verifikasi hasil pengukuran alat ukur radiasi guna memantau dosis radiasi yang diterima oleh pasien dan pekerja radiasi. Sedangkan bagi para dokter radiasi onkologi, hasil penelitian dapat bermanfaat dalam treatment pasien dengan efektif.

\section{METODE PENELITIAN}

Perangkat lunak komputasi yang digunakan pada penelitian ini dalam bentuk pemodelan transportasi radiasi dengan menggunakan Monte Carlo N-Particle-5 (MCNP-5). Program MCNP-5 digunakan untuk mensimulasi perhitungan dosis radiasi pada jaringan tumor dengan tahapan penelitian seperti berikut ini. 
Tahap awal dilakukan perancangan dan pembuatan input file berupa cell cards, surface cards dan data cards. Pada tahap ini, pembuatan parameter simulasi MCNP dan code-nya termasuk pendefinisian sel, permukaan sel, material sel.

Pada tahap berikutnya merupakan perancangan dan pembuatan source definition dan tally specification. Termasuk di dalamnya, memposisikan masing-masing sumber dan alat ukur serta pembuatan code-nya, kemudian pendefinisian sumber dan fiturnya sesuai propertinya serta pembuatan code-nya.

Setelah code program selesai dibuat, kemudian dikompilasi untuk memastikan kebenaran code yang dibuat. Bila kompilasi sudah berjalan dengan baik, baru kemudian program dieksekusi untuk menghitung dosis yang diserap organ tubuh manusia/sel 1 (dalam penelitian ini berupa jaringan tumor di payudara) sesuai dengan variabel pengubah yaitu komposisi sel 2, besar sel 2, jarak sumber radiasi ke sel 2 dan energi sumber radiasi diperoleh dari Barium 137 dengan energi radiasinya mendekati $0.678 \mathrm{Mev}$.

Dalam penelitian ini, besar volume tumor dapat divariasi sehingga sesuai dengan besar tumor yang sesungguhnya dan pada kondisi volume tersebut dapat dilakukan simulasi dengan program MCNP. Melalui simulasi penelitian ini, dapat diketahui besar energi yang diabsorbsi tumor setiap detik dan dapat juga diektrapolasi untuk berapa lama radiasi dilakukan sehingga total radiasi tidak melebihi 50 Gray (Skowronek \& Chicheł 2014).

\section{HASIL DAN PEMBAHASAN}

Salah satu contoh koding program untuk menghitung dosis serap pada sel 1, yang dibuat dengan MCNP-5 adalah seperti terdapat pada Tabel 1 di bawah ini. Koding ini telah mendefinisikan sel, komposisi sel dan batas sel dengan sel, sumber energi dan besaran fisika yang akan dihitung. Dalam hal ini besar dosis serap oleh sel 1 yang akan dihitung sebagai fungsi perubahan komposisi sel, besar sel dan jarak sumber terhadap sel. Sebelum program ini dieksekusi, terlebih dahulu dilakukan uji kompilasi program. Hasil uji kompilasi yang benar dapat terlihat dengan hasil tampilan seperti Gambar 1.

Tabel 1. Contoh koding program Fortran untuk menghitung dosis radiasi di sel 1

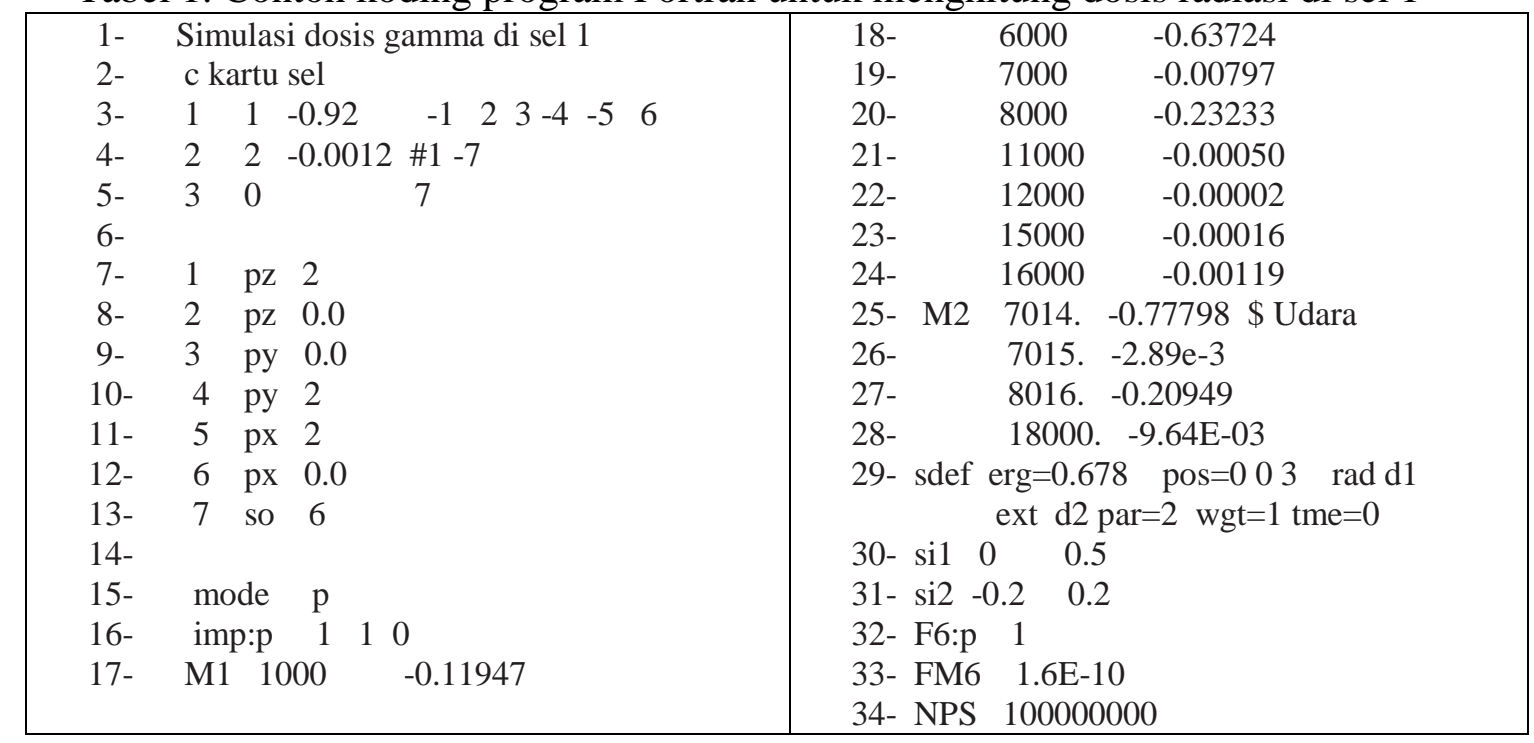


Hasil kompilasi program yang dibuat dengan program aplikasi MCNP-5 (Gambar 1) menunjukkan adanya objek yang diasumsikan sebagai tumor dalam tubuh pasien, yang direpresentasikan oleh sel 1 yang berbentuk kubus. Posisi sel 1 dalam ruang koordinat $\mathrm{x}$, y dan $\mathrm{z}$ berada pada koordinat $(\mathrm{x}=2, \mathrm{y}=2$ dan $\mathrm{z}=2)$. Objek sel 1 dikelilingi oleh sel 2 yang berbentuk bola yang tumpang tindih dengan sel 1. Jari-jari sel 2 yaitu $6 \mathrm{~cm}$ dari titik asal koordinat sumbu $\mathrm{x}$, y dan z. Sedangkan diluar sel 2 adalah sel 3 yang tidak didefinisikan dalam program, karena setiap paparan radiasi yang keluar dari sel 2 menuju perbatasan dengan sel 3 diasumsikan bernilai nol. Sumber energi paparan radisi sebesar $0.678 \mathrm{MeV}$, berada pada sumbu koordinat $\mathrm{x}=0, \mathrm{y}=0$ dan $\mathrm{z}=3$. Radiasi dipancarkan melalui media tertentu, kemudian mengenai tumor. Besar dan komposisi sel 1,2 serta besar dan nilai energi sumber paparan merupakan nilai variabel, yang dapat diubah dalam simulasi program.

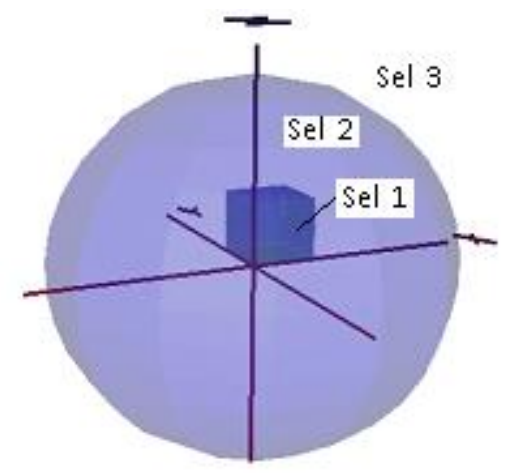

Gambar 1. Hasil kompilasi program MCNP-5

Dalam program simulasi ini, akan dihitung dosis radiasi pada sel 1, sedangkan besar nilai dosis di sel 1, dipengaruhi oleh keadaan posisi sumber, energi sumber, komposisi sel 1 dan sel 2. Besar dosis di sel 1, berdasarkan komposisi sel 1 dan 2 dan besar sel 1 terdapat pada Tabel 2 berikut ini.

Tabel 2. Hasil simulasi perubahan jarak, besar sel dan komposisi sel dengan program MCNP-5

\begin{tabular}{|c|c|c|c|c|c|c|}
\hline No. & $\begin{array}{l}\text { Jarak sumber } \\
\text { dari objek } \\
{[\mathrm{cm}]} \\
\end{array}$ & $\begin{array}{l}\text { Energi sumber } \\
\text { (Barium 137) } \\
{[\mathrm{Mev}]}\end{array}$ & $\begin{array}{l}\text { Sisi } \\
\text { kubus } \\
\text { [cm] } \\
\end{array}$ & $\begin{array}{l}\text { Komposisi } \\
\text { sel } 1\end{array}$ & $\begin{array}{l}\text { Komposisi } \\
\text { sel } 2\end{array}$ & $\begin{array}{l}\text { Energi/dosis di sel } 1 \\
\text { [Gray] }\end{array}$ \\
\hline 1 & 3 & 0.678 & 2 & adipora & udara & $4.9810 \times 10 \mathrm{e}-14$ \\
\hline 2 & 3 & 0.678 & 2.2 & adipora & udara & $5.0741 \times 10 \mathrm{e}-14$ \\
\hline 3 & 3 & 0.678 & 2.4 & adipora & udara & $5.1693 \times 10 \mathrm{e}-14$ \\
\hline 4 & 3 & 0.678 & 2.6 & adipora & udara & $5.3118 \times 10 \mathrm{e}-14$ \\
\hline 5 & 3 & 0.678 & 2 & adipora & udara & $4.9055 \times 10 \mathrm{e}-14$ \\
\hline 6 & 3.2 & 0.678 & 2 & adipora & udara & $4.2420 \times 10 \mathrm{e}-14$ \\
\hline 7 & 3.4 & 0.678 & 2 & adipora & udara & $3.7001 \times 10 \mathrm{e}-14$ \\
\hline 1 & 3 & 0.678 & 2 & air & udara & $7.3010 \times 10 \mathrm{e}-14$ \\
\hline 2 & 3 & 0.678 & 2.2 & air & udara & $7.4177 \times 10 \mathrm{e}-14$ \\
\hline 3 & 3 & 0.678 & 2.4 & air & udara & $7.5336 \times 10 \mathrm{e}-14$ \\
\hline 4 & 3 & 0.678 & 2.6 & air & udara & $7.7146 \times 10 \mathrm{e}-14$ \\
\hline 5 & 3 & 0.678 & 2 & air & udara & $7.3010 \times 10 \mathrm{e}-14$ \\
\hline 6 & 3.2 & 0.678 & 2 & air & udara & $6.3151 \times 10 \mathrm{e}-14$ \\
\hline 7 & 3.4 & 0.678 & 2 & air & udara & $5.5094 \times 10 \mathrm{e}-14$ \\
\hline 1 & 3 & 0.678 & 2 & kulit & udara & $4.9055 \times 10 \mathrm{e}-14$ \\
\hline 2 & 3 & 0.678 & 2.2 & kulit & udara & $4.9957 \times 10 \mathrm{e}-14$ \\
\hline 3 & 3 & 0.678 & 2.4 & kulit & udara & $5.0876 \times 10 \mathrm{e}-14$ \\
\hline 4 & 3 & 0.678 & 2.6 & kulit & udara & $5.2256 \times 10 \mathrm{e}-14$ \\
\hline
\end{tabular}




\begin{tabular}{lllllll}
\hline $\begin{array}{l}\text { No. } \\
\text { Jarak sumber } \\
\text { dari objek } \\
{[\mathbf{c m}]}\end{array}$ & $\begin{array}{l}\text { Energi sumber } \\
\text { (Barium 137) } \\
{[\mathbf{M e v}]}\end{array}$ & $\begin{array}{l}\text { Sisi } \\
\text { kubus } \\
{[\mathbf{c m}]}\end{array}$ & $\begin{array}{l}\text { Komposisi } \\
\text { sel 1 }\end{array}$ & $\begin{array}{l}\text { Komposisi } \\
\text { sel 2 }\end{array}$ & $\begin{array}{l}\text { Energi/dosis di sel 1 } \\
{[\text { Gray] }}\end{array}$ \\
\hline 5 & 3 & 0.678 & 2 & kulit & udara & $4.9055 \times 10 \mathrm{e}-14$ \\
\hline 6 & 3.2 & 0.678 & 2 & kulit & udara & $4.2420 \times 10 \mathrm{e}-14$ \\
\hline 7 & 3.4 & 0.678 & 2 & kulit & udara & $3.7001 \times 10 \mathrm{e}-14$ \\
\hline
\end{tabular}

Tabel 2 kolom 7 terdapat hasil simulasi program berupa dosis yang diserap oleh sel 1, sedangkan kolom 5 dan 6 adalah jenis materi yang ada di sel 1 dan sel 2. Dan kolom 2, 3 dan 4 berturut turut berupa jarak sumber terhadap sel 1, energi sumber dan sisi kubus sel 1.

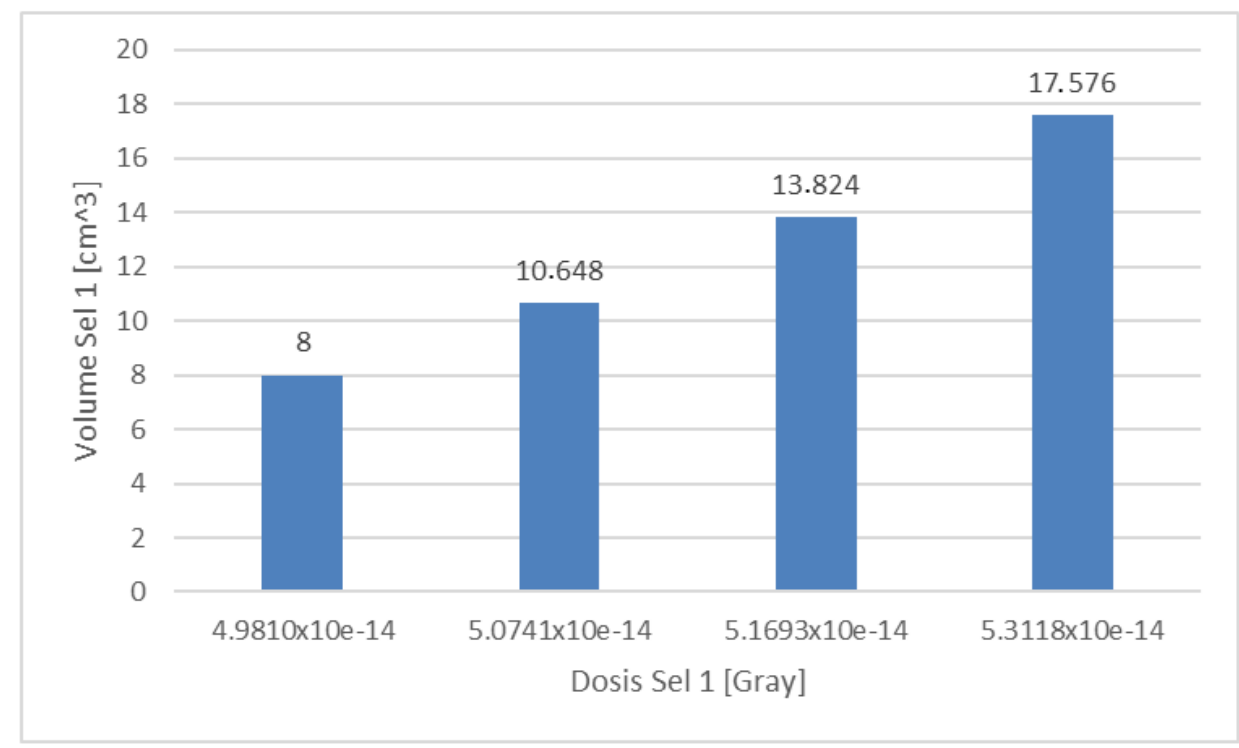

Gambar 2. Perubahan volume sel 1 terhadap dosis serapnya untuk materi sel 1 adipora dan sel 2 air.

Gambar 2 menunjukkan pengaruh perubahan volume sel 1 terhadap besar dosis yang diserap oleh sel 1. Besar energi radiasi sinar gamma sebesar $0,678 \mathrm{MeV}$, pada posisi awal berada sejauh $3 \mathrm{~cm}$ dari sel 1, namun dengan pertambahan volume sel 1, tentu ada perubahan jarak yang semakin berkurang sebanding dengan pertambahan volume sel 1. Sumber ini memancarkan sinar gamma melewati udara, sebagai sel 2 dan memasuki materi adipora atau mirip dengan materi tumor (sel 1). Gambar tersebut menunjukkan bahwa semakin besar volume sel 1 maka dosis yang diserap oleh sel 1 juga semakin bertambah. 


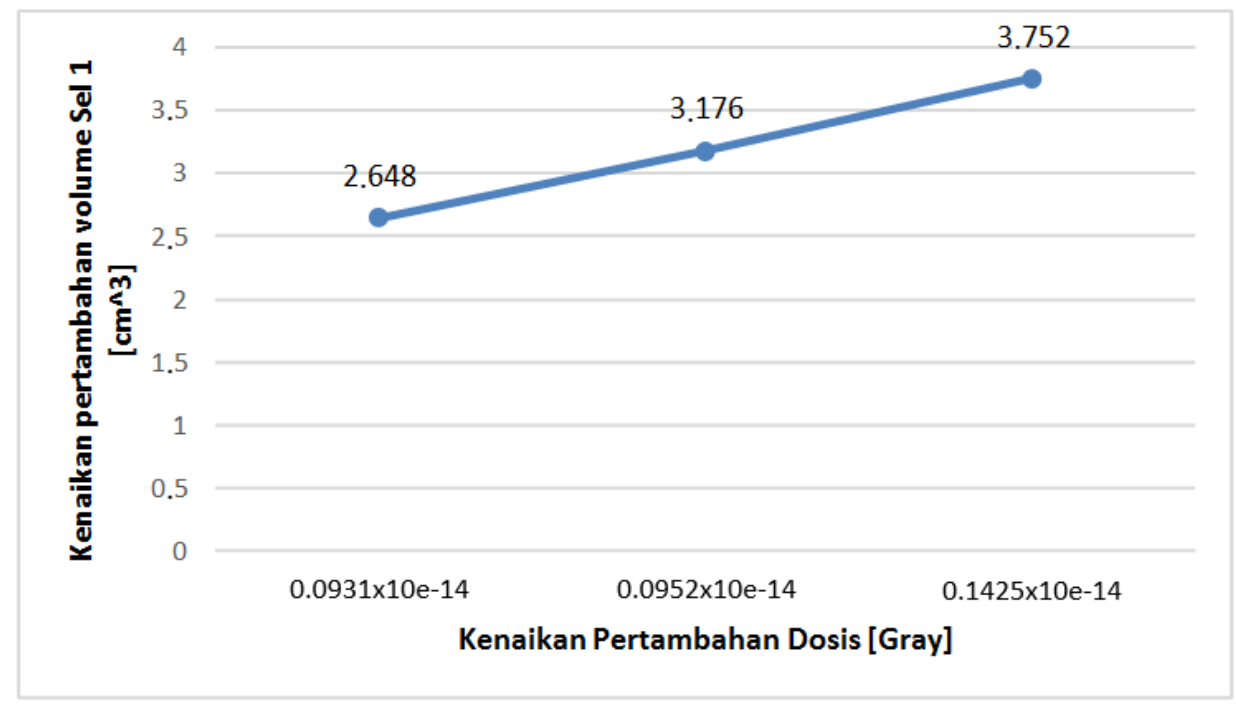

Gambar 3. Pengaruh kenaikan volume sel 1 terhadap kenaikan dosis serapnya untuk materi sel 1 adipora dan sel 2 air.

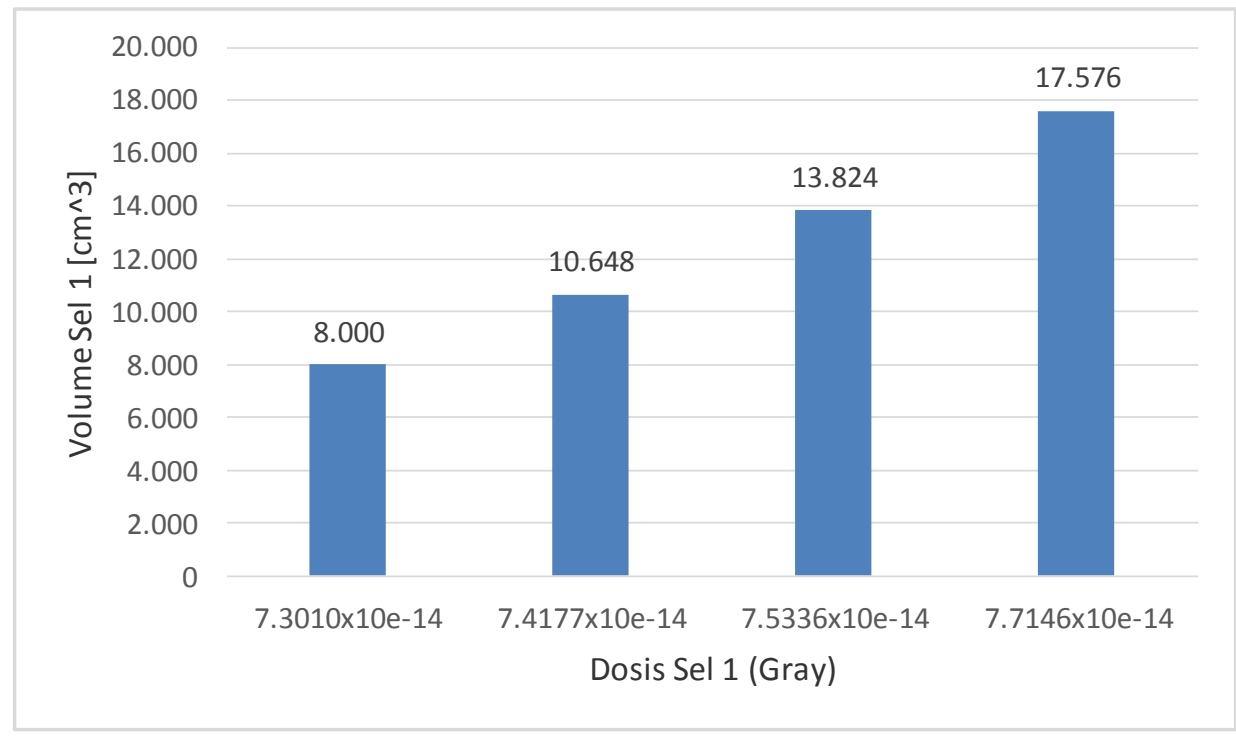

Gambar 4. Perubahan volume sel 1 terhadap dosis serap di sel 1 untuk materi sel 1 air dan sel 2 udara

Gambar 3 menunjukkan hubungan pengaruh kenaikkan pertambahan volume Sel 1 terhadap kenaikan pertambahan dosis yang diserap oleh sel 1. Akibat penambahan sebesar $2,648 \mathrm{~cm}^{3}$ volume sel 1, dapat mengakibatkan pertambahan dosis serap sebesar 0,0931x10e-14 Gray dengan kata lain untuk kenaikan $1 \mathrm{~cm}^{3}$ terjadi penambahan energi serap oleh sel 1 sebesar 3,5x10e-12 Gray, nilai ini relatif sangat kecil sekali dan data ini masih memerlukan koreksi akibat adanya perubahan jarak yang semakin berkurang sebanding dengan pertambahan volume sel 1. Sedangkan Gambar 4 menunjukkan pengaruh perubahan volume sel 1 terhadap dosis serap sel 1, dimana materi sel 1 bukan adipora melainkan air dan sel 2 tetap berupa materi udara. Pada Gambar 4 terlihat adanya pertambahan dosis radiasi yang diserap oleh sel 1 sebagai akibat 
pertambahan volume sel 1 . Pertambahan dosis serap tersebut untuk kenaikan volume $1 \mathrm{~cm}^{3}$ air adalah sebesar 4,40x10e-12 Gray. Hal ini menunjukkan bahwa daya serap air terhadap penyerapan energi gamma akibat pertambahan volume yang sama, lebih besar dibanding dengan adipora. Secara keseluruhan, semakin besarnya volume sel 1 untuk materi adipora/jaringan tumor, air dan kulit maka memiliki tren yang sama yaitu dosis yang diterima sel 1 semakin besar juga.

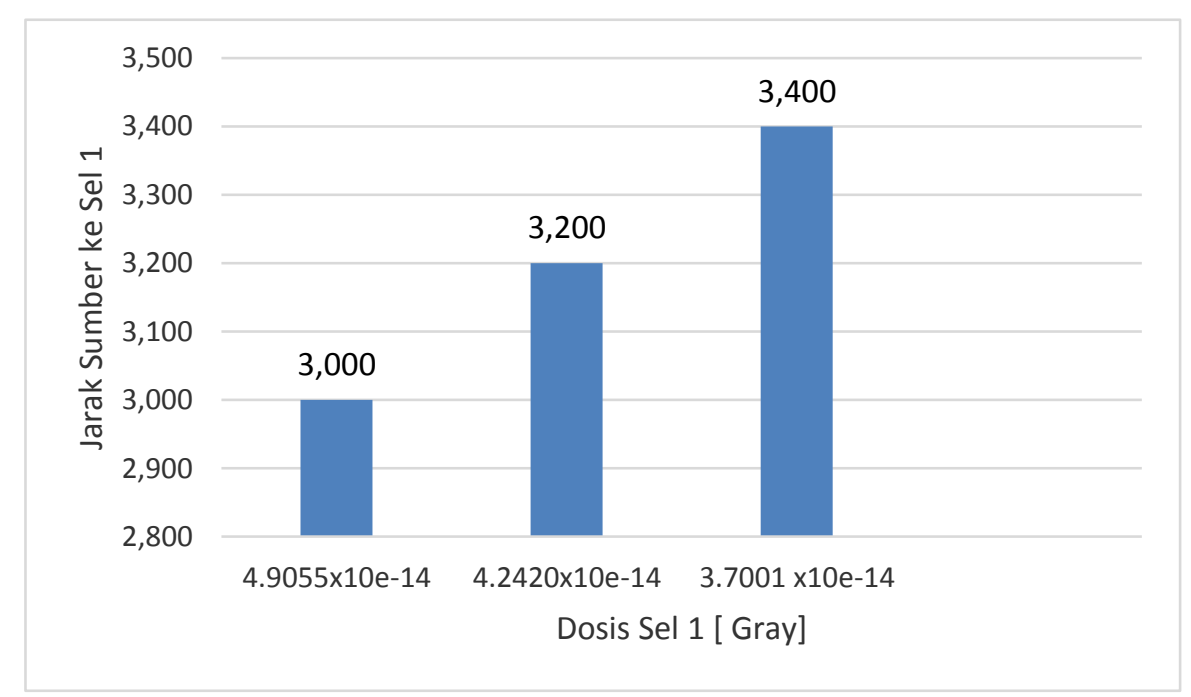

Gambar 5. Perubahan jarak sumber terhadap dosis serap di sel 1 untuk materi sel 1 adipora dan sel 2 air

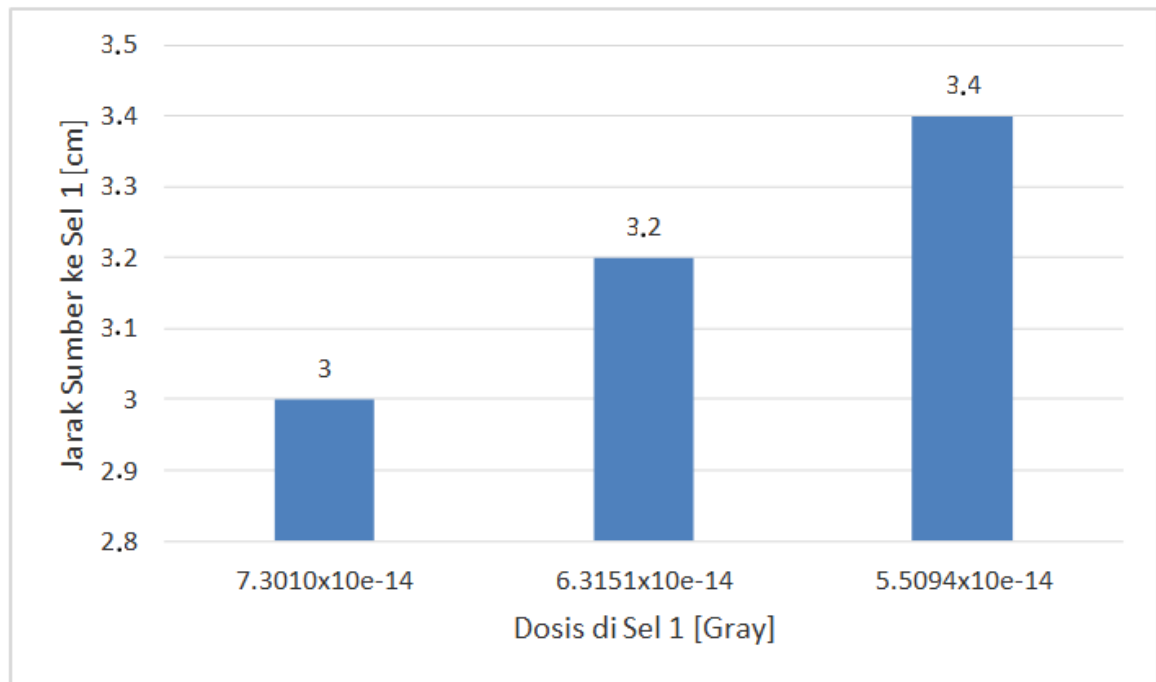

Gambar 6. Perubahan jarak sumber ke sel 1 terhadap dosis serap di sel 1 untuk materi sel 1 air dan sel 2 udara

Gambar 5 dan 6 menunjukkan adanya perubahan dosis serap oleh sel 1 baik materi adipora (Gambar 5), maupun materi air (Gambar 6) ketika jarak antara sumber energi berubah. Energi serap semakin rendah apabila jarak sumber energi semakin besar. Hal ini berlaku juga untuk sel 1 yang berupa materi kulit. Secara garis besar penurunan dosis tampak lebih besar pada sel 1 dengan materi air dibandingkan dengan sel 1 materi adipora. 


\section{KESIMPULAN DAN SARAN}

Penelitian ini telah melakukan analisis dosis serap radiasi gamma pada jaringan tumor di payudara dengan mengaplikasikan simulasi program MCNP-5. Melalui simulasi program aplikasi MCNP-5 telah dapat diketahui untuk setiap penambahan $1 \mathrm{~cm}^{3}$ volume adipora atau tumor dapat meningkatkan energi serap pada sel 1 sebesar 3,5x10e-12 Gray, nilai ini relatif sangat kecil sekali. Sedangkan bila sel 1 materinya adalah air, variabel lainnya adalah sama menunjukkan ada pertambahan dosis radiasi sebesar 4,40x10e-12 Gray. Nilai ini dapat berguna untuk pendekatan awal terhadap penentuan besar energi yang diberikan pada pada pasien dengan pertimbangan besar tumor jarak tumor dengan sumber radiasi dan materi yang dilalui oleh radiasi.

Hasil penelitian ini menunjukkan juga bahwa dosis serap radiasi pada sel 1 untuk materi adipora, air dan kulit akan semakin menurun bila jarak antara sumber radiasi dengan sel 1 semakin besar. Untuk pertambahan volume sel 1 tersebut maka kecenderungan dosis yang diterima sel 1 semakin besar juga.

Penelitian ini masih terbatas pada sumber radiasi yang sangat ideal yaitu berupa sebuah titik, untuk studi lebih lanjut dapat dilakukan penelitian terhadap faktor-faktor bentuk dan besar energi sumber radiasi yang lebih bervariasi.

\section{Ucapan Terima Kasih}

Penulis mengucapkan terima kasih atas dukungan dari Universitas Matana sehingga penelitian ini dapat direalisasikan.

\section{REFERENSI}

Aznar, M. C., Medin, J., Hemdal, B., Thilander Klang, A., Bøtter-Jensen, L., Mattsson, S. (2005). A Monte Carlo study of the energi dependence of al2o3:c crystals for real-time in vivo dosimetry in mammography. Radiation Protection Dosimetry. 114(1-3), 444-449. doi:10.1093/rpd/nch560

Bor D., Tukel S., Olgar T., Aydin E., (2008). Variations in breast doses for an automatic mammography unit. Diagn. Interv. Radiol. 14:122-126.

Dance, D.R. (1990). Monte Carlo calculation of conversion factors for the estimation of mean glandular breast dose. Phys. Med. Biol., 35(9), 1211-1219.

Diffey, J., Cartwright, L., Crocker, J., Heggie, J. (2014). Direct half value layer measurements in mammography-is near enough good enough? Combined Scientific Meeting. DOI:10.1594/ranzcr2014/R-0127

Douglas, E. P., Kuruvilla, V. (2000). Digital mammography image simulation using Monte Carlo. Medical Physics, 27(568). doi: 10.1118/1.598896

Koutalonis, M., Delis, H., Spyrou, G., Costaridou, L., Tzanakos, G., Panayiotakis, G. (2007). Contrast-to-noise ratio in magnification mammography: a Monte Carlostudy. Phys. Med. Biol. 52. 3185-3199. doi:10.1088/0031-9155/52/11/017

Olgar, T, Kahn, T., Gosch, D. (2012). Average Glandular Dose in Digital Mammography and Breast Tomosynthesis. Fortschr. Röntgenstr. 184, 911-918. DOI: 10.1055/s-00321312877.

Pandiangan, T., Bali, I., Silalahi, A.R.J. (2019). Early lung cancer detection using artificial neural network. Atom Indonesia, 45(1), 9-15. https://doi.org/10.17146/aij.2019.860 
Pandiangan, T., Bali, I., Silalahi, A. (2020). The use of MNCP-5 particle transport program for calculation of flux radiation exposure in object surface. IOP Conf. Ser.: Mater. Sci. Eng., 852, 012174. https://doi.org/10.1088/1757-899X/852/1/012174

Ramos, M.A.P., Ferrer, S., Verdu, G., Padovani, E., Campayo, J.M. (2004). A mammographic phantom image reconstruction through Monte Carlo techniques. Nuclear Science Symposium Conference Record, IEEE, 5. DOI: 10.1109/NSSMIC.2004.1466322

Sechopoulos, I., Suryanarayanan, S., Vedantham, S., D'Orsi, C.J., Karellas, A. (2007). Computation of the glandular radiation dose in digital tomosynthesis of the breast. Med Phys. 34(1), 221-232. doi: 10.1118/1.2400836

Sechopoulos, I., Suryanarayanan, S., Vedantham, S., D'Orsi, C.J., Karellas, A. (2008). Radiation dose to organs and tissues from mammography: Monte Carlo and phantom study". Radiology, 246(2), 434-443. DOI: 10.1148/radiol.2462070256

Skowronek J. (2017). Current status of brachytherapy in cancer treatment - short overview. $J$ Contemp Brachytherapy, 9(6):581-589. doi:10.5114/jcb.2017.72607

Skowronek J, Chicheł A. (2014). Brachytherapy in breast cancer: an effective alternative. Prz Menopauzalny, 13(1):48-55. doi:10.5114/pm.2014.41090 
(halaman ini sengaja dikosongkan) 